\title{
A Hogarth Press Timeline
}

1915 The Woolfs decide to buy a printing press and Hogarth House at Richmond.

1917 (1 title) purchase of printing press; hand print 134 copies of Two Stories (with Dora Carrington woodcuts).

1917-23 Hogarth Press publishes almost exclusively literature (Willis 213).

1918 (2 titles) Mansfield's Prelude (68 pages); Woolfs are approached by Harriet Shaw Weaver regarding Joyce's Ulysses (they refuse it).

1919 (4 titles) VW's Kew Gardens; Woolfs use commercial printer for the first time for second edition; Hogarth Press publishes first poetry, Eliot and Murry; the Press begins travelling books more seriously; closure of Omega Workshop (in operation since 1913).

1920 (4 titles) Forster's Story of the Siren; translation of Gorky's Reminiscences of Tolstoy (printed by Pelican Press; according to Willis, the Woolfs' first commercial enterprise; with this, Willis writes, the Woolfs became 'a small scale international publisher' (80)). Ralph Partridge taken on as assistant (-1923); first Hogarth Press advertisements (in the Nation, TLS); first real profits.

1920-23 (27 titles) 8, or nearly one-third, of which are Russian translations.

1921 (6 titles) the Hogarth Press establishes a relationship with Harcourt Brace in the USA. The Woolfs purchase a Minerva platen printing press. LW's Stories of the East; VW's Monday or Tuesday, Gorky's Notebooks of Tchekhov.

1922 (6 titles) 5 years! VW's first Hogarth Press novel, Jacob's Room (first book to be printed by R. \& R. Clark of Edinburgh); Bunin's The Gentleman from San Francisco; more commercially printed books than hand printed for the first time; first pictorial Hogarth Press dust jacket by Vanessa Bell (her first for the Press); merger offers rejected. 
1923 (11 titles, 5 hand set) Eliot's The Waste Land; Forster's Pharos and Pharillon; Read; Bell; Graves (first of 3 books of poetry and 3 of criticism); Marjorie Joad joins the Press; LW becomes literary editor at The Nation and Athenaeum (-1930).

March, 1924 Move to 52 Tavistock Square.

Mid 1920s-mid 1930s Continue with literature, and over 50 books and pamphlets on domestic social and economic issues added to Press' list (Willis 239).

1924-30 VW dominates at the Press, according to Willis.

1924-late 1930s 8 pamphlets on Russia, communism and Marxism.

1924 (17 titles, 3 hand set) F. M. Mayor's The Rector's Daughter (on a commission basis); Sackville-West's Seducers in Ecuador; publish first socio-political title, Norman Leys' Kenya; begin Hogarth Essays series (1928, 35 titles); begin relationship with International PsychoAnalytical Library (IPL); decide against publishing a translation of Gide by Dorothy Bussy; Dadie Rylands joins the Press (stays only 6 months).

1925 (27 titles, 4 hand set) LW's first non-fiction Hogarth Press publication, Fear and Politics: A Debate at the Zoo; Muir's First Poems and 8 other volumes of poetry; first of 11 titles on women (Willis 244) (Willa Muir's Women: An Inquiry followed by Leisured Women in 1928); first of 3 titles on India (Thompson's The Other Side of the Medal); VW's Mrs. Dalloway and Common Reader; Mrs Cartwright joins the Press as manager. Sylvia Beach is stocking Hogarth Press titles at her Shakespeare and Co. in Paris.

1925-6 Hogarth Press publishes 3 of J. M. Keynes' shorter works.

1926 onwards Only one or two hand-set books per year.

1926 (30 titles) Plomer's first novel Turbott Wolfe (Hogarth Press' eighth novel); first cheap edition (third edition of Leys' Kenya); second in series of publications by Katherine Innes on international politics for young readers; first in series of publications on peace and disarmament (by Philip Noel-Baker); first of 2 publications by Laura Riding.

1927 (38 titles) Lectures on Literature (-1934, 16 titles); first of annual Merttens Lecture on War and Peace (at Hogarth Press 192730; 1934-6); Freud's Ego and Id; Muir's The Marionette; 'Virginia Woolf's greatest artistic and commercial success [and] peak years for the Hogarth Press' (Willis 134), Kauffer's first cover and new logo for Hogarth Press; Hogarth Press begins a relationship with the Garden City Press in Letchworth (chief printer, among more than 30, for the Press). Alice Ritchie joins the Press as a part-time traveller.

1928 (36 titles) VW's Orlando (best-seller); Living Poets series edited until 1932 by Dorothy Wellesley (-1937, 29 titles). 
1929 (30 titles) Uniform Editions of VW's books (Willis says this 'marked one more stage in the evolution of the Hogarth Press into a commercial publishing house' (155)). First of number of titles on education (Starr's Lies and Hate in Education).

1930s Press issued an average of 8 titles per year on a variety of political and social issues (Willis 259); following Russian translations in the 1920s, translations of Svevo and Rilke appear in the 1930s.

1930 (29 titles) launch Day to Day Pamphlets; Sackville-West's Edwardians (best-seller). Margaret Llewelyn Davies' Life as we have known it. Maximum profits in 1930 and 1931 of approximately $£ 2,300$ (exceeded only in 1937).

1931 (35 titles) Lehmann joins the Press and his poems are published; Easdale's A Collection of Poems; Kitchin's The Sensitive One; Hampson's best-selling Saturday Night at the Greybound; Letters series (-1933, 12 titles); LW's After the Deluge; VW's The Waves.

1932 (36 titles) the Woolfs cease hand printing; Lehmann departs Press. Michael Roberts' New Signatures in the Living Poets series (Auden, Spender); Plomer's The Case Is Altered.

1933-6 Political books outnumber literary (Willis 213).

1933 (20 titles) Michael Roberts' New Country; Mussolini's The Political and Social Doctrine of Fascism (Day to Day Pamphlet); Derrick Leon's middlebrow Livingstones.

1934 (24 titles) Laurens van der Post's In a Province; Parmenas Mockerie's An African Speaks for his People.

1935-7 Only 6 volumes of poetry.

1935 (24 titles) Isherwood's Mr Norris Changes Trains; LW's Quack, Quack!

1936 (23 titles).

1937 (20 titles) World-Makers and World-Shakers (4 titles); VW's The Years; death of press manager Margaret West, replaced by Dorothy Lange then Norah Nicholls (1938-40); first salaried book traveller, Barbara Hepworth.

1938 (17 titles) Lehmann returns to the Press as partner and managing director $(-1946)$, brings Folios of New Writing to the Press; Isherwood's Lions and Shadows (sold 1699 copies in first three months); Upward's Journey to the Border; VW's Three Guineas.

1939 (23 titles) mid August 1939 Hogarth Press moves to Mecklenburgh Square; Lehmann launches Sixpenny Pamphlets (5 titles, first of which is Forster's This I Believe) and Poets of Tomorrow (-1941, 3 titles); Henry Green's Party Going; Christopher Isherwood's Goodbye to Berlin. 
1940 (10 titles) Lehmann launches New Hogarth Library (-1941, 6 titles); VW's Roger Fry; paper rationing introduced.

1941 (8 titles) In March, VW's death; Between the Acts published posthumously; translation of Rilke's selected poems.

1942 In April, LW and Lehmann reject Sackville-West's novel Grand Canyon.

\section{Works cited}

Willis, J. H. Leonard and Virginia Woolf as Publishers: The Hogarth Press, 1917-41. Charlottesville: University Press of Virginia, 1992. 